\title{
Localization of Pantoea ananatis inside lesions of maize White Spot Disease using transmission electron microscopy and molecular techniques
}

\author{
Cleide A. Bomfeti ${ }^{1}$, Edneia A. Souza-Paccola ${ }^{1}$, Nelson S. Massola Júnior ${ }^{2}$, Ivanildo E. Marriel ${ }^{3}$, Walter F. \\ Meirelles $^{3}$, Carlos R. Casela ${ }^{3} \&$ Luzia D. Paccola-Meirelles ${ }^{1}$ \\ ${ }^{1}$ Departamento de Biologia Geral, Universidade Estadual de Londrina, 860051-990, Londrina, PR, Brazil; ${ }^{2}$ Departamento \\ de Entomologia, Fitopatologia e Zoologia Agrícola, ESALQ, Universidade de São Paulo, 13418-900, Piracicaba, SP, Brazil; \\ ${ }^{3}$ Embrapa Milho e Sorgo, 35701-970, Sete Lagoas, MG, Brazil
}

Corresponding author: Luzia D. Paccola-Meirelles, e-mail: paccola@uel.br

\begin{abstract}
The etiological agent of maize white spot (MWS) disease has been a subject of controversy and discussion. Initially the disease was described as Phaeosphaeria leaf spot caused by Phaeosphaeria maydis. Other authors have suggested the existence of different fungal species causing similar symptoms. Recently, a bacterium, Pantoea ananatis, was described as the causal agent of this disease. The purpose of this study was to offer additional information on the correct etiology of this disease by providing visual evidence of the presence of the bacterium in the interior of the MWS lesions by using transmission electron microscopy (TEM) and molecular techniques. The TEM allowed visualization of a large amount of bacteria in the intercellular spaces of lesions collected from both artificially and naturally infected plants. Fungal structures were not visualized in young lesions. Bacterial primers for the $16 \mathrm{~S}$ rRNA and rpoB genes were used in PCR reactions to amplify DNA extracted from water-soaked (young) and necrotic lesions. The universal fungal oligonucleotide ITS4 was also included to identify the possible presence of fungal structures inside lesions. Positive PCR products from water-soaked lesions, both from naturally and artificially inoculated plants, were produced with bacterial primers, whereas no amplification was observed when ITS4 oligonucleotide was used. On the other hand, DNA amplification with ITS4 primer was observed when DNA was isolated from necrotic (old) lesions. These results reinforced previous report of $P$. ananatis as the primary pathogen and the hypothesis that fungal species may colonize lesions pre-established by $P$. ananatis.
\end{abstract}

Keywords: maize bacterial disease; maize leaf disease; Zea mays.

\section{RESUMO}

Localização da bactéria Pantoea ananatis no interior de lesões da doença Mancha Branca do Milho por meio de microscopia eletrônica de transmissão e técnicas moleculares

O agente etiológico da mancha branca do milho (MBM) tem sido alvo de discussão e controvérsia. Inicialmente a doença foi descrita como sendo a mancha foliar de Phaeosphaeria causada por Phaeosphaeria maydis. Outros autores sugeriram a existência de diferentes espécies fúngicas provocando sintomas semelhantes. Recentemente a bactéria Pantoea ananatis foi descrita como sendo o agente causal desta doença. O objetivo deste estudo foi oferecer informações adicionais sobre a correta etiologia da doença proporcionando evidências visuais da presença da bactéria no interior de lesões da MBM por meio de microscopia eletrônica de transmissão (MET) e técnicas moleculares. A MET permitiu visualizar um grande número de células bacterianas nos espaços intercelulares em lesões oriundas de plantas naturalmente e artificialmente infectadas. Estruturas fúngicas não foram visualizadas em lesões jovens. Primers bacterianos para os genes $16 \mathrm{~S}$ rRNA e rpoB foram usados em reações de PCR para amplificar DNA extraído diretamente de lesões jovens e de lesões necróticas. O oligonucleotídeo universal para fungo, ITS4, foi incluído para identificar a possível presença de estruturas fúngicas nas lesões. Amplificação positiva foi obtida com primers bacterianos, a partir de lesões jovens, natural e artificialmente inoculadas, enquanto que nenhuma amplificação foi observada quando o oligonucleotídeo ITS4 foi usado. Amplificação do DNA com o primer ITS4 foi observada quando o DNA foi extraído de lesões em estádio avançado de necrose. Estes resultados reforçam relatos anteriores que descrevem $P$. ananatis como patógeno primário da doença e a hipótese de que espécies fúngicas podem colonizar lesões pré - estabelecidas pela $P$. ananatis.

Palavras-chave: Doença bacteriana do milho, doenças foliares do milho, Zea mays.

Maize white spot disease has contributed to significant yield reduction in maize crops in Brazil since the 1990's due to its high incidence and severity in all maize growing areas of the country. The symptoms of the disease begin with the appearance of slightly chlorotic and water-soaked spots on the leaf surface of susceptible genotypes, that later become necrotic and straw colored. Lesions can be circular or elliptic, measure 0.3 to $1 \mathrm{~cm}$ in diameter (Fernandes \& Oliveira, 1997; Paccola-Meirelles et al., 1998), and can coalesce becoming irregular in shape. Disease expression varies depending on the plant genotype (Paccola-Meirelles et al., 2002). 
The disease was, initially, described as Phaeosphaeria leaf spot (Fantin, 1994), caused by the ascomycete Phaeosphaeria maydis, anamorph Phyllosticta sp. (Rane et al., 1966). However, several authors have reported difficulty in isolating (Cervelatti et al., 2002; Amaral et al., 2002) and fulfilling Koch's postulates with this fungus (Cervelatti et al., 1998; 2002; Paccola- Meirelles et al., 2001; Amaral et al., 2002). Paccola- Meirelles et al. (2001) isolated a Gramnegative bacterium, bright yellow colony-forming from the lesions at the initial stages of the disease, the so-called watersoaked lesions. This bacterium was identified as Pantoea ananatis (Serrano, 1928) and, when inoculated in maize plants, under controlled conditions, reproduced symptoms similar to those observed in the field, under natural infection. The bacterium was then reported by these authors as the causal agent of the disease.

Another hypothesis was later raised by Amaral et al. (2005) who described three species of fungi, other than P. maydis, causing this disease: Phyllosticta sp., Phoma sorghina, and Sporormiella sp. According to these authors, the occurrence of each one of the specific agents depends upon environmental conditions and may vary between cropping areas and seasons in Brazil.

The main objective of this work was to demonstrate, by means of transmission electron microscopy (TEM) and molecular techniques, the presence of the bacterium in the initial (young) lesions of artificially inoculated leaves of susceptible maize plants, to reinforce the previous report of $P$. ananatis as the causal agent of MWS.

Water soaked lesions were collected from different maize producing areas around Londrina (PR) to assess the isolation frequency of the bacterium in this location. After collection, maize leaves were washed with neutral soap. A total of 718 lesions were then removed from the leaves and treated in $70 \%$ alcohol ( $1 \mathrm{~min}$ ), $2 \%$ Chloramin $\mathrm{T}$ (4 min), $70 \%$ alcohol $(30 \mathrm{sec})$ and washed three times for 30 seconds in sterilized water. The edges of each segment containing a lesion were then removed (approximately $1 \mathrm{~mm}$ ) with a sterile scalpel, and lesion ends were cut and transferred to TSA medium. Water from the last wash was plated out on trypticase soy agar (TSA) to evaluate the efficiency of the disinfection procedure.

A bright yellow-colored bacterium, typical of $P$. ananatis, as described by Paccola et al. (2001), was the organism most frequently obtained from the isolation process. After isolation, the bacterium was purified in TSA medium and cultivated in trypticase soy broth (TSB) medium for 12 hours at $28^{\circ} \mathrm{C}$. A suspension containing $10^{6} \mathrm{CFU}$ was prepared in a $0.85 \%$ saline solution and inoculated on 30-day old maize plants of the cultivar BRHS200. Microhumidity chambers containing 12 inoculation wells (Bergstrom \& Nicholson, 1983) were used for the inoculations. After placing the chambers over the maize plants, the leaves were slightly injured with a micro needle and each well of the chamber received $50 \mu \mathrm{l}$ of bacterial suspension. Control plants received the same treatment, but were treated with a $0.85 \%$ saline solution. After 60 hours the chambers were removed and the plants kept in a greenhouse until the development of symptoms.

Water-soaked lesions obtained from artificially inoculated plants, lesions at different development stages obtained from naturally infected plants in the field, and leaf segments without lesions (derived from control plants in the greenhouse and from the field) were collected and processed by standard techniques to be analyzed by TEM. Samples were fixed in modified Karnovsky's solution (2.5\% glutaraldehyde, $2.5 \%$ paraformaldehyde in $0.05 \mathrm{M}$ cacodylate sodium buffer, $\left.\mathrm{pH} 7.0+\mathrm{CaCl}_{2} 0.001 \mathrm{M}\right)$. Twenty-four hours later, which includes five minutes under vacuum infiltration, tissues were washed in $0.05 \mathrm{M}$ cacodylate sodium buffer $(3 \mathrm{x}$ $10 \mathrm{~min}$ ) and post-fixed in $1 \%$ osmium tetroxide in the same buffer for two hours. Samples were then washed in distilled water ( $3 \times 10 \mathrm{~min})$, dehydrated in a gradual acetone series (30\%, 50\%, 70\%, 90\% and 3x100\%), embedded in Spurr's epoxy resin and $100 \%$ acetone $(1: 1)$ for five hours, and transferred to pure resin for 12 hours. Samples were then polymerized at $70^{\circ} \mathrm{C}$ for 48 hours in silicone molds. Sections $(80 \mathrm{~nm})$ were cut in a microtome (Leica Ultracut UCT) with a diamond knife (Diatome), collected in formvar-coated 100 -mesh nickel grids. After staining with uranyl acetate and lead citrate, they were examined under a Zeiss EM 900 transmission electron microscope (NAP-MEPA- ESALQ/ USP-Piracicaba/SP).

For the molecular analyses, DNA was extracted directly from water-soaked and necrotic lesions obtained in the field from naturally infected material. Diseased leaves were washed with neutral soap and the lesions chopped. About $1 \mathrm{~g}$ of both soaked and necrotic lesions were squashed in liquid nitrogen and the total DNA extracted according to the technique reported by Doyle and Doyle (1987). The control was made using lesion-free leaf segments. The DNA fragments were amplified by PCR reactions using the following oligonucleotides: ITS4 (Internal Transcribed Spacer of the rDNA - universal for fungi), and sequences of the gene codifying for 16S rRNA (16S DNAr) and the gene codifying the $\beta$ subunit of the RNA polymerase (rpo $\beta$ ) (bacteria-specific).

The amplification reactions were prepared for a final reaction volume of $45 \mu \mathrm{l}(5 \mu \mathrm{L}$ of $10 \mathrm{X}$ Taq Buffer; $1 \mu \mathrm{L}$ of $2.5 \mathrm{mM}$ dNTP's; $2 \mu \mathrm{L}$ of $20 \mu \mathrm{M}$ Primers; $0.5 \mu \mathrm{L}$ of $5 \mathrm{U} / \mu \mathrm{L}$ Taq DNA Polymerase- Life Technologies - Brazil; $5 \mu \mathrm{L}$ of DNA; $2.5 \mu \mathrm{L}$ of $2 \mathrm{mM} \mathrm{MgCl} ; 25 \mu \mathrm{L}$ of $\mathrm{H}_{2} \mathrm{O}$ ).

The amplification conditions were $1^{\prime}-94^{\circ} \mathrm{C}, 1^{\prime}$ $50^{\circ} \mathrm{C}, 90^{\prime \prime}-72^{\circ} \mathrm{C}$, during 40 cycles. All the reactions were finalized with an extension at $72^{\circ} \mathrm{C}$ for $7 \mathrm{~min}$. A negative control was made for each initiator oligonucleotide, where the DNA of the reaction was replaced with water. The gels were stained with ethidium bromide $(0.5 \mu \mathrm{g} / \mathrm{ml})$ and visualized under ultraviolet light; the images were captured and stored in a photo documentation system (Eagle Eye II, STRATAGENE).

A Gram-negative bacterium with smooth mucoid 
colony, bright yellow pigmentation, typical of $P$. ananatis, was the isolate predominantly obtained from the 718 watersoaked lesions. The isolation frequency of this bacterium was $40 \%$, similar to the frequency obtained by PaccolaMeirelles et al. (2001).

Inoculations in the greenhouse, carried out with the bacterial isolate, allowed reproduction of disease symptoms five to seven days after inoculations. The leaves first developed dark green soaked lesions, typical of initial stages of the disease, confirming the results obtained by PaccolaMeirelles et al. (2001). Symptoms were not observed on the control plants.

Transmission electron microscopy analyses (Figure 1) revealed the presence of a large number of bacteria inside young water-soaked type lesions of the maize white spot disease. The bacteria were located in the intercellular spaces; they were rod-shaped 0.25 to $0.5 \mu \mathrm{m}$ wide and 1.0 to $3.0 \mu \mathrm{m}$ long, both in lesions collected in the field (Figure 1b) and those obtained from artificial inoculation (Figure 1d). A significant disorganization in the leaf tissue was also observed. Bacteria were not observed in healthy samples (Figure 1a and 1c) and no fungal structures were seen in watersoaked lesions either from artificially inoculated or naturally infected plants. These results offer visual confirmation of the presence of the bacterium inside the young lesions of maize white spot disease, in agreement with the report by PaccolaMeirelles et al. (2001).

PCR reactions with specific primers for fungi and bacteria confirmed the presence of the bacteria in the watersoaked lesions (Figure 2). Single and expressive bands were obtained when DNA of the field lesions was amplified with bacteria-specific sequences 16S DNAr (Figure 2a)
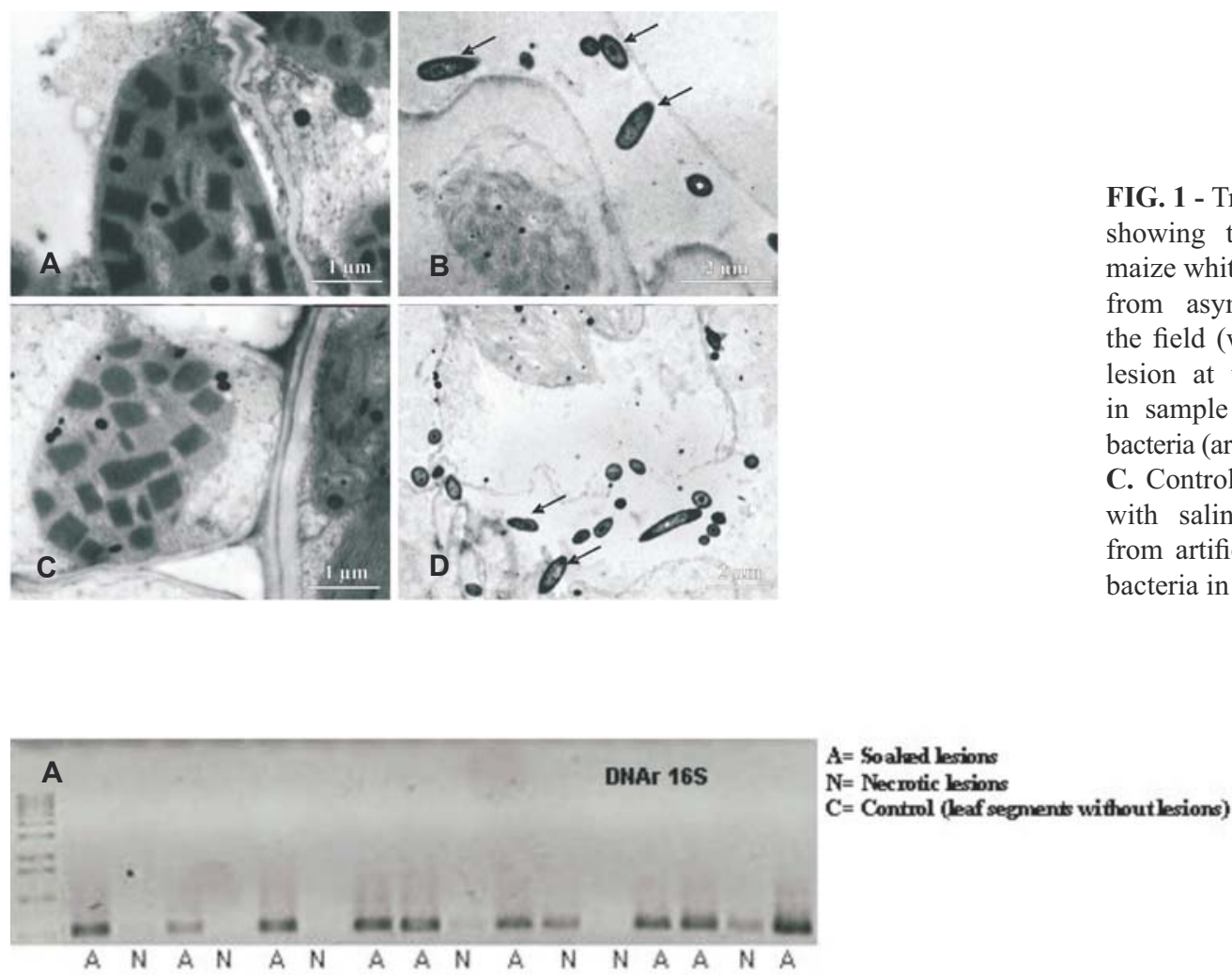

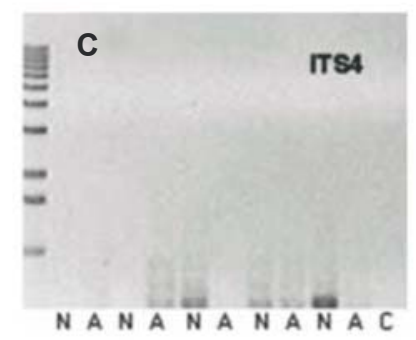

FIG. 1 - Transmission Electron Micrographs showing the presence of bacteria inside maize white spot lesions. A. Control: section from asymptomatic sample collected in the field (without lesions); B. Section from lesion at the initial stage of the disease, in sample collected in the field, showing bacteria (arrows) in the intercellular space (IS); C. Control: section from artificially treated with saline solution sample; D. Section from artificially inoculated lesion, showing bacteria in the intercellular space (arrows).

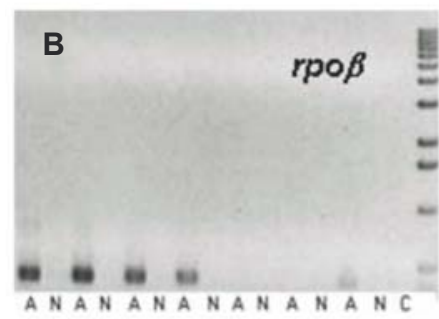

Tropical Plant Pathology 33 (1) January - February 2008
FIG. 2 - PCR reactions from the total DNA extracted from soaked (A) and necrotic (N) lesions and control leaf segments without lesions (C). A. DNA amplification with $16 \mathrm{~S}$ DNAr primer specific for bacteria; B. DNA amplification with the rро $\beta$ primer specific for bacteria; C. DNA amplification of the lesion with ITS4 primer for fungi. 
and rpo $\beta$ (Figure 2b). On the other hand, amplification was not observed in the water-soaked lesions treated with ITS4 (Figure 2c), indicating absence of fungi in young lesions. Field necrotic lesions did not amplify with the 16S DNAr (Figure 2a) and rpo $\beta$ (Figure 2b) sequences. Amplification with the ITS4 olignonucleotide occurred only in some samples containing lesions at advanced stages of necrosis (Figure 2c). These results suggest a decrease in the bacterial population as the lesion became necrotic and an increase in the population of fungi which could colonize lesions in the necrotic phase of the disease.

Results of the present study complement those previously reported by Paccola - Meirelles et al. (2001), which identified $P$. ananatis as the causal agent of the disease. The fact that fungal structures were detected in lesions preestablished by the bacteria when they become necrotic may explain the diversity of species of fungi isolated by some authors from necrotic lesions.

\section{ACKNOWLEDGMENTS}

The authors thank Conselho Nacional de Desenvolvimento Científico e Tecnológico - CNPq, Fundação Araucária Paraná and Universidade Estadual de Londrina for financial support.

\section{REFERENCES}

do Amaral AL, dal Soglio FK, Wernz Neto AW, Pegoraro DG., Vaccaro E, Fantin G.M, Barbosa Neto JF (2002) Determinação de agentes causais de manchas semelhantes à mancha de Phaeosphaeria em Milho (Zea mays). Anais, XXIV Congresso Nacional de Milho e Sorgo, Florianópolis SC. (CD ROM).

do Amaral AL, dal Soglio FK, de Carli ML, Barbosa Neto JF (2005) Pathogenic fungi causing symptoms similar to Phaeosphaeria leaf spot of maize in Brazil. Plant Disease 89:44-49.

Bergstrom G.C, Nicholson RI (1983) Microhumidity chamber for quantitative inoculation of attached corn leaves with fungal pathogens. Phytopathology 73:1040-1042.

Cervelatti EP, Fernandes FT, Paccola-Meirelles LD (1998) Caracterização citológica de Phyllosticta sp. (Phaeosphaeria maydis). Anais, XXII Congresso Nacional de Milho e Sorgo, Recife, PE. (CD ROM)

Cervelatti EP, Paiva E, Meirelles WF, Casela CR, Fernandes FT, Teixeira FF, Paccola-Meirelles LD (2002) Characterization of fungal isolates from pycnidia and pseudothecia from lesions of phaeosphaeria leaf spot in maize (Zea mays). Revista Brasileira de Milho e Sorgo 3:30 - 37.

Doyle JJ, Doyle JL (1987) A rapid DNA isolation procedure from small quantities of fresh leaf tissues. Phytochemistry Bulletin, Botanical Society of America 19:11-15.

Fantin GM (1994) Mancha de Phaeosphaeria, doença do milho que vem aumentando sua importância. Biológico, São Paulo SP $56: 39$.

Fernandes FT, Oliveira E (1997) Principais Doenças na Cultura do Milho. Sete Lagoas MG. Embrapa Milho e Sorgo. Circular Técnica 26.

Paccola-Meirelles LD, Meirelles WF, Cervelatti EP, Maki CS, Casela CR, Fernandes FT, Ferreira AS (1998) Caracterização morfológica das lesões da mancha foliar por Phaeosphaeria em híbridos de milho e avaliação da incidência do estágio sexuado e assexuado do patógeno. Anais, XXII Congresso Nacional de Milho e Sorgo, Cuiabá, MT. (CD ROM).

Paccola-Meirelles LD, Ferreira AS, Meirelles WF, Marriel IE, Casela CR (2001) Detection of a bacterium associated with a leaf spot disease of maize in Brazil. Journal of Phytopathology 149:275-79.

Paccola-Meirelles LD, Meirelles WF, Parentoni SN, Marriel IE, Ferreira AS, Casela CR (2002) Reaction of maize inbred lines to a bacterium Pantoea ananas, isolated from Phaeosphaeria leaf spot lesions. Plant Breeding and Applied Biotechnology 2:587-590.

Rane MS, Payak MM, Renfro BL (1966) The Phaeosphaeria leaf spot of maize. Indian Phytopathological Society Bulletin 3:8-10. 